\title{
Law Enforcement in Indonesia in Perspective of Transcendental Legal Justice Paradigm
}

\section{Siti Kasiyati}

Fakultas Syariah IAIN Surakarta

kasiyati_siti@yahoo.com

DOI: $10.23917 /$ jtl.v2i2.11855

\author{
Submission \\ Track: \\ Received: \\ 31 July 2020 \\ Final Revision: \\ 21 December 2020 \\ Available online: \\ 29 December 2020 \\ Corresponding \\ Author: \\ Siti Kasiyati \\ kasiyati_siti@yahoo.com
}

\begin{abstract}
Law enforcement in Indonesia still leaves various problems, especially regarding the sense of justice. Such as diffable cases dealing with the law, civil cases, especially in the land sector, which relies on property rights certificates, cases of domestic violence (nusyuz).
\end{abstract}

In this case, this study discusses how law enforcement in Indonesia is, and how law enforcement is in the perspective of the transcendental justice paradigm. This research is a literary research using secondary data sources, namely primary and secondary legal materials. This study includes a normative study with a synthetic analytic approach.

Based on the results of the analysis, law enforcement in Indonesia, both criminal and civil, is still fixated on legal certainty, thus ignoring substantive justice. This is where a shift is needed from the paradigm of law enforcement based on legal certainty to transcendent justice. This condition can be seen from several decisions that are very formalistic and based on laws, where legal certainty is the front line compared to substantive justice so that justice is not felt by the public. This condition is also strongly influenced by the legal paradigm adopted in Indonesia, namely positivist law or known as the systemic legal paradigm. Transcendental starts from irrational and metaphysical thinking such as emotions, feelings, instincts, moral spirituality and as part of building science. In this context, law enforcement. The perspective of the transcendental legal justice paradigm highlights how the purpose of Islamic law is useful for justice and human welfare. Where the law is based on ethics (morals) so that it can produce substantive justice, not mere formalistic justice, which summarizes the human attitude to 
be fair to God as the creator, fair to fellow humans and fair to the universe.

Keywords: Law Enforcement, Transcendental Justice Paradigm

\section{INTRODUCTION}

The condition of Law Enforcement in Indonesia is still very formalistic and adheres to the existence of laws, where legal certainty is the front line compared to substantive justice so that justice is not felt by the public. This condition is also strongly influenced by the legal paradigm adopted in Indonesia, namely positivist law or also known as the systemic law paradigm, where the truth adopted is the truth that comes from reason, not law that comes from God.

This is very different from the law that comes from God or revelation. The tug-of-war between the truths of this law has become a very long discourse among legal experts. The natural law, for example, prefers law that comes from God as an option to validate the truth, but this has received criticism. This is due to some stagnation in implementation.

According to Shidarta, the strictness of legal positivism to eliminate the requirements for connectivity between law and morals creates axiology. This concept is only limited to achieving legal certainty. The core of legal certainty is predictability, namely the ability to perceive "an individual ought to behave in certain say". The axiological aspect that legal positivism strives for is legal certainty, by taking a formal source in the form of legislation it is believed that this can be realized as follows (Shidarta, 2006):

1. Law as ideas, moral values and justice

2. Law as norms, rules, regulations, laws that apply at a certain time and palce as a product of the power of a certain sovereign state; and

3. Law as a real and functional social institution in a social life system which is formed from institutionalized behavior patterns.

There are differences regarding the concept of law. This is because the approaches that are influenced are different. The existence of law is closely related to human existence, because the structure of its existence is shared with others in the world, and humans are 
intelligent and have a conscience. Thus, studying the law can be carried out in various perspectives, this reflects how the law lives in society. (Sidharta, 1999, p. 186)

Based on this, there should be a single concept of what is called the law. Law is a sociocultural reality, whose conceptual construction will be arranged differently from one perspective to another. The law, in itself has the nature of "multi-facets" and "multi-logic", for that reason, views that law can be studied from different dimensions, even though law still contains the value behind the rule is value, a value that means justice, prosperity, happiness, order. Therefore, the law must serve humanity and the benefit of humans, not the other way around.

According to Absori, rational reasoning and inner connectivity that humans have, lead to a rhythm of awareness of the truths of science. The concept of positivism comes from a way of teaching that law is regulatory, applies as a whole, and is stipulated by the authority of the ruling state. In addition, Hans Kelsen argued that law is described as a sterile (valuefree) domain, separate from ethical and moral.

In the context of positive law, it indirectly ignores the function of humans as law enforcers and how justice is built not only in a rational dimension and independent of morals and ethics. In fact, according to Ibn Miskawaih, human happiness is if they are able to carry out virtues and ethics so that they can lead to Shari'ah law as mentioned above. The freedom of thought possessed by humans is in order that humans can be fair to themselves, God and the universe.

Based on the explanation above, this research will discuss first, how to enforce the law in Indonesia, and second, how to enforce the law with the perspective of transcendental justice paradigm.

\section{RESEARCH METHOD}

This research is a literary study using secondary data sources, namely primary and secondary legal materials. This study includes a normative study with a synthetic analytic approach. Borrowing a term from Kuntowijoyo, which will later convey the concepts in Qur'an about justice and actions about justice offered by Muslim philosophers to uphold justice. 
In this context, the author wants to offer a transcendental non-systemic legal paradigm by taking a study of the objectives of law and justice offered by Muslim philosophers, namely Ibn Miskawaih and Imam Assyatibhi’s Justice.

\section{DISCUSSION}

\section{Law Enforcement in Indonesia}

Law enforcement in Indonesia is still influenced by posivistic legal understandings that emphasize legal certainty. In this study, several examples of cases of law enforcement that prioritize legal certainty will be described, namely those related to cases of disabilities, cases of women and cases of land ownership.

Law enforcement that prioritizes legal certainty occurs in cases of people with disabilities who are victims of criminal acts. In this condition, law enforcers who prioritize legal certainty cause law enforcers to not understand, disrespect, the condition of victims of diffable, one of which is a lack of evidence resulting in the loss of justice that is received from people with diffable. This situation encourages activists of legal aid organizations and diffable organizations to be involved in advocating for cases of diffables who are victims of criminal acts. This can assist law enforcers in the investigation, prosecution and trial processes.

Below are some cases of diffable victims of violence who have failed to get justice, namely:

\begin{tabular}{llll}
\hline \multicolumn{1}{c}{$\mathbf{z}$} & $\begin{array}{c}\text { Criminal } \\
\text { Act }\end{array}$ & $\begin{array}{l}\text { The } \\
\text { Perpetrator }\end{array}$ & \multicolumn{1}{c}{ Legal Proceedings } \\
\hline $\begin{array}{l}\text { Mental } \\
\text { retardation } \\
\text { hearing } \\
\text { impairment }\end{array}$ & Rape & $\begin{array}{l}\text { Owner of an } \\
\text { enterprise }\end{array}$ & $\begin{array}{l}\text { The case stops at the police level } \\
\text { because of the possibility of } \\
\text { distortion of test evidence and there } \\
\text { is intervention from village officials } \\
\text { with a family settlement mechanism. }\end{array}$ \\
\hline $\begin{array}{l}\text { Mental } \\
\text { retardation }\end{array}$ & Rape & $\begin{array}{l}\text { Close } \\
\text { neighbors }\end{array}$ & $\begin{array}{l}\text { The case stopped at the police level } \\
\text { because the victim was unable to } \\
\text { testify due to obstacles and } \\
\text { communication difficulties. }\end{array}$ \\
\hline $\begin{array}{l}\text { Mental } \\
\text { retardation }\end{array}$ & Rape & Brother & $\begin{array}{l}\text { The perpetrator was released } \\
\text { because the victim was not } \\
\text { traumatized. }\end{array}$ \\
\hline
\end{tabular}




\begin{tabular}{llll}
\hline Slow learner & Rape & Neighbor & $\begin{array}{l}\text { Cases cannot be processed and stop } \\
\text { at the police level because the } \\
\text { witness is also a slow learner. }\end{array}$ \\
\hline Blind & Rape & $\begin{array}{l}\text { Massage } \\
\text { patient }\end{array}$ & $\begin{array}{l}\text { The case stopped at the police level } \\
\text { because of a lack of evidence. }\end{array}$ \\
\hline Deaf speech & Rape & $\begin{array}{l}\text { Close related } \\
\text { person }\end{array}$ & $\begin{array}{l}\text { The case was stopped due to lack of } \\
\text { evidence and difficulty } \\
\text { understanding the victim's language. }\end{array}$ \\
\hline Paraplegia & $\begin{array}{l}\text { Domestic } \\
\text { Violence }\end{array}$ & Husband & $\begin{array}{l}\text { Stopped at the police level because } \\
\text { of family pressure to withdraw the } \\
\text { case. }\end{array}$ \\
\hline $\begin{array}{l}\text { Metal } \\
\text { retardation }\end{array}$ & Rape & Neighbor & $\begin{array}{l}\text { The family chose not to continue the } \\
\text { case at the suggestion of the head of } \\
\text { the neighborhood association }\end{array}$ \\
\hline
\end{tabular}

Apart from cases of disabilities, unjust law enforcement also often occurs in women. As is the case with victims of domestic violence against women who find it difficult to get substantive justice. In these conditions, women have to leave the house so as not to become victims of further violence, but they are often cut off by nusyuz (disobedient husband). Other civil cases, for example the matter of property rights, as the main evidence is the Certificate of Ownership, even though there is often a process of transferring rights due to the previous owner's ignorance. This case can be seen from the case No. 01/Pdt.Plw/2016/PN SKH.

Legal failures that occurred in Indonesia as in the case above were greatly influenced by the Positivism system. Where law is defined as positive norms in the statutory system. From the ontology point of view, this meaning reflects the combination of idealism and materialism. An explanation of this can be found in John Austin's The Will Theory of Law and Hans Kelsen's The Pure Norm Theory of Law.

According to John Austin, "A positive legal rule is to be equated with the expression of an act of wishing," while "A legal system is to be equated with all the positive legal rules emanating from the same sovereign will". Therefore, "..the notion of law as a command of the sovereign. Anyting that is not a command is not law. Only general command counts as law. And only commands emanating from the sovereign are 'positive law'."(Hart, 2006, p. 245)

H.L.A. Hart (in Sidharta: 2006) gies a description of the term Positivism as follows: 
"The expression 'positivism' is used in contemporary Anglo-American literature to designate one or more of the following contentions: 1) that laws are commands of human being; 2) that there is no necessary connection between law and morals, or law as it is and law as it ought to be; 3) that the analysis or study of meanings of legal concepts is an important study to be distinguished from (though in no way hostile to) historical inquiries, sociological enquiries, and critical appraisal of law in terms of morals, social aims, functions, \& $c$; 4) that a legal system is a 'closed logical system' in which correct decisions can be deduced from predetermined legal rules by logical means alone; 5) that moral judgements cannot be established, as statements of fact can, by rational argument, evidence or proof (non cognitivism in ethics). Bentham and Austin held the views expressed in 1, 2, and 3 but not those in 1 and 4. Contention 4 is often ascribed to 'analytical jurists' but apparently without good reason". In continental literature the expression 'positivism' is often used for the general repudiation of the claim that some principles or rules of human conduct are discoverable by reason alone.

For positivism, there is no law other than positive law, which is law based on sovereign authority. For positivism, positive law is different when compared to other principles based on morality, religion, social customs. This positivism concept greatly exalts written law, so that this school assumes that there is no legal norm outside positive law, all problems in society are regulated in written law. The view that really glorifies written law in this legal positivism, is in fact an excessive respect for the power that created the written law, so that this power is considered the source of law of the rule of law.(Isra, 2018, p. 235) Positivism law or commonly known as Ius Constitutum, which is the law that applies now to a certain society in a certain area. In short, a law that applies to a society at a time, in a particular place (Sapoetra, 1983, p. 163).

Hans Kelsen is anti-empirical and not anti-positivist. After listening to the quotations of his thoughts, it will be clear that Kelsen is actually a positivism (Hans Kelsen is more emphasized in the teachings of pure legal theory, namely teachings that see the law as really sollenskategorie (should be) and not as a seinskategorie (it is), free from all non-juridical elements such as sociology and ethnicity).

\section{Trancendental Law Enforcement Paradigm}


Justice is the nature of law. Where law enforcers have a duty and responsibility in creating justice for society. Satjipto Rahardjo promotes progressive legal theory as a criticism of the positivist domination in Indonesia that indirectly eliminates justice in enforcing the law.

Based on progressive law, that law must side with the people. Justice must be placed above the rules. Law enforcers must have the courage to break through the rigidity of the regulatory text which is termed "law mobilization" if the text messes with people's sense of justice. Progressive law aims to bring people to prosperity and happiness. The law must have a further purpose than that proposed by liberal philosophy. Where the liberal philosophy of law must prosper and make people happy.

In this context, Satjipto Raharjo's thoughts are in accordance with Imam Ibn Miskawaih's thoughts on the virtues of the soul, spiritual intelligence, justice and humanity, as well as Maqoshidusyyari'ah according to Imam As-Syatibiy. Where between the law and the enforcer must pay attention to the interests of humans, law for humans. The thought of Islamic law that was carried out by Muslim philosophers in the year 87 Hijriah and almost never became a reference for legal experts including in the law faculty in Indonesia, which is predominantly Muslim. This spiritual intelligence was also offered by Imam Ibn Miskawaih.

This idea is also supported by Bernat Arif Sidarta, in which the development of law in Indonesia should be able to create a legal system that protects, welfare, guarantees order, peace and justice the Indonesian people, so that Indonesian law can serve as a protector. In this sense, the law of protection implies protecting humans passively (negatively) by preventing arbitrary actions, and actively (positively) by creating social conditions that enable social processes in a fair and just manner by providing wide opportunities for every human being to develop all of their human potential as a whole. The law of protection is carried out by means of making things happen:

1. Discipline and order that gives rise to predictability;

2. Peaceful serenity;

3. Justice (distributive, komutative, vindikative, protektive, dan preferentive);

4. Welfare and social justice;

5. Development of noble morals based on Belief in the one and only God. (Ibid) 
Thus, in this study the author offers a study on shifting the legal certainty paradigm to transcendental-based justice. Transcendental what is meant in this study is how Islamic law teaches justice to all humankind. Whereas in reality, positive law used in law enforcement in Indonesia only departs from rationality that leaves religion, morals and ethics. Even though the law is for humans. The law must have a substantive justice dimension, not just formalistic justice.

According to Absori, the transcendental legal paradigm is a legal paradigm that can be taken from religion, ethics and morality. Religion, ethics and morals are not only one aspect but are closely related to doctrinal theology and worship. Transcendental starts from irrational and metaphysical thoughts such as emotions, feelings, instincts, moral spirituality and as part of building science. In this context the transcendental paradigm we offer is transcendental in Islam.(Absori, 2019)

The development of transcendental laws, especially Islamic law, also experiences problems in its enforcement if it relies only on the meaning of normativity. The effort to shift the meaning of Islamic law from normativity to collectivity becomes the basic idea to keep Islamic law as the pioneer of human legal compliance. The desire for Islamic law to move from mahdhah to ghairu mahdhah has become the vision of Islamic legal experts in every discourse that is carried out. From here, philosophical materials related to law move, with the hope that the study of Islamic legal philosophy will become the origin for the emergence of humanist Islamic law. The existing law in Muslim countries, including Indonesia, is currently very much dominated by a positive and rational paradigm that relies on legal certainty.

As it is known that justice is a commandment of Allah. There are several Nash Qur'an and hadiths about the command to do justice. As stated in surah al Hujuraat verse 9:

"And if two factions among the believers should fight, then make settlement between the two. But if one of them oppresses the other, then fight against the one that oppresses until it returns to the ordinance of Allah. And if it returns, then make settlement between them in justice and act justly. Indeed, Allah loves those who act justly."

Another term that the Qur'an uses to denote fair meaning is al-qist, which originally meant the fate of an-nasib bil-adl-equitable distribution. This verse has a different meaning from Qur'an surah Al-Maidah verse 8: “O you who have believed, be persistently standing 
firm for Allah, witness in justice, and do not let the hatred of a people prevent you from being just. Be just; that is nearer to righteousness.” (Al-Ma`idah/5:8)

Apart from the Nash Qur'an, there is also the Prophet Muhammad's hadith regarding justice as follows: "No one has power over a matter in this umma (Muhammad's ummah), then he does not do justice among them, unless Allah SWT will throw him to hell" (History of Ma'qil) (Al-hasyimi, 1993, p. 782). Nash's theorem and the hadith above show that justice is a means of providing human benefit.

In answering the study of how Islamic law teaches justice to all humankind, the author wants to use the approach of Imam Ibn Miskawaih in offering his ideas. Apart from the fact that Ibn Miskawaih was an expert on Islamic philosophy and law, the resulting thought was very rational but did not leave revelation. If Imam Assyatibi's thoughts focus more on how the purpose of Islamic law is to benefit justice and human welfare. Imam Ibn Miskawaih seems to complement how to make a perfect human being an enforcer of justice and ethics that can make someone can do justice. This seems to be in line with Soerjono Soekanto's view that the effectiveness of law is determined by the Law itself and its enforcers.

The transcendental approach using the Islamic legal philosophy approach aims so that Islamic law can be studied fundamentally to the most basic things in the discussion of Islamic law itself, while at the same time opening opportunities for legal experts to have in-depth knowledge of law so as to make legal experts or anyone believe more in the truth of Islamic teachings contained in Islamic law. Therefore a philosophical approach in the study of Islamic law is very important because it is useful for establishing law (Izomiddin, 2018, p 42). The philosophy of Islamic law is knowledge of the nature, secrets and objectives of good Islamic law concerning its material, as well as the process of determining it (Syarifuddin, op. cit., p. 16), Here the role of law enforcers is very significant in upholding justice.

As mentioned above, in the view of Islam, law comes from Allah, and in developing it the role of a mujtahid or legal expert is very important. Like how the purpose of law formulated by Imam Assythibi is for benefit, law cannot be separated from values, ethics and morals. 
In his work al-Muwafaqot, al-Syatibi uses different words related to maqoshid as syari'ah. The words are maqoshid as-syari'ah, al-maqsadah as-syari'ah fiasy-syari'ah almaqoshid min syari'I al hukm. According to him, shari'ah aims to create the benefit of humans in this world and the hereafter. This study departs from the view that all obligations (taklif) are created in order to realize the benefit of the people. There is no law of God which has no purpose. Laws that have no purpose are the same as taklif mala yuthoq (impose something that cannot be implemented), something that cannot happen to God's laws.(Asy Syatibi, tt, p. 2-3)

In realizing benefit in the world and the hereafter, based on the research of ushul fiqh experts, there are five main elements that must be maintained and realized. The five main elements are religion (hifz al-din), soul (hifz al-nafs), mind (hifz al aql), heredity (hifz alnasl), dan treasure (hifz al-mal). In an effort to realize and maintain the five main elements, al-Syatibi divided into three levels of maqhosid or shari'ah goals, namely the first, maqhosid al-dharuriyat (primary purpose), This maqhosid is intended to maintain the five main elements in human life. Second, Maqoshid al Hajiyat (secondary purpose), its purpose is to eliminate difficulties or make the maintenance of the five main elements better. Third, Maqhosid al-tahsiniyat (tertiary goals), the intention is that humans can do their best to improve the maintenance of the five main elements.

According to Imam Al-Syatibi, the doctrine of maqoshid as-syari'ah is a continuation and development of the concept of maslahah as proclaimed before the time of al-Syathibi. According to him, the unity of Islamic law means unity in its origins and even more so in its legal reference. In order to uphold the purpose of this law, he put forward his teachings, namely the good and welfare of humankind.

Meanwhile Ibn Miskawaih (932-1030 AD) lived the era of the Abbasid Caliphate. He spoke a lot in his work Tahdzib al-Akhlaq. In this book, he formulates concepts to build an ethic that can bring happiness to individuals and society. Because according to Ibn Miskawaih, morality is a state of the soul of a person that encourages doing good deeds, without first considering thoughts.

As a law enforcer, borrowing Miskawaih's term as a human being, first, the existence of the nature of the body makes humans bound by space, time, and material laws. The existence of the essence of the soul makes humans able to have a relationship with God, 
creating culture and civilization. Second, there is a structural and functional relation between the agency as a material substance and the soul as an immaterial human substance, not an essential immaterial human relationship. Third, the goal of human life is to achieve perfection, relating it to the behavior and special characteristics possessed, namely the faculty of thinking. Fourth, the conception of Insan Kamil emphasizes the power and glory of the faculty of thinking that makes humans leave instincts, shahwiyah lust and anger towards shari' ah law and the wisdom of thinking, so that they can reach the highest position in the human realm.(Bakri, 2018, p. 147)

Transcendental is always intended to worship and submit to Allah's law, even though reason is given space with its reasoning power to achieve excellence and produce devout souls. The transcendence offered by both Imam Asyathibi and Ibn Miskawaih completely guides people to reach Insan Kamil who in their axsiology can bring about justice as mentioned above. The balance of the soul between the characteristics of wild beasts, bahimiyah and nathiqoh in the guidance of revelation will certainly produce spiritual intelligence and the ability of a mujtahid (legal expert) not based on mere lust of anger. This is where the transcendental justice dimension of law is relevant. Where law is based on ethics (morals) so that it is able to produce substantive justice instead of mere formalistic justice, where there is a summary of human attitudes to be fair to God as the creator, fair to fellow humans and fair to the universe.

In this context, when humans have reached this level, they will create goodness in their lives so that they will achieve happiness (Sa'adah). Systematically it can be seen from Ibn Miskawaih's thoughts on ethics, among others:

a. Kindness dan happiness

According to Ibn Miskawaih, as written by Malik, kindness is a state where we reach the final limit and perfection of form. General kindness is good for all humans in their position as humans. Meanwhile, special kindness is good for someone personally. Kindness in this last form is called happiness. Kindness has a certain identity that is generally accepted by humans, whereas happiness varies depending on the people who seek it.

The notion of happiness has been widely discussed by Greek thinkers of which there are basically two versions, namely the first view represented by Plato, saying that only the 
soul can experience happiness. Therefore, as long as human is alive or as long as the soul is connected to the body, so long as this happiness will not be obtained.(Miskawaih, 1999, p. 40-41)

b. Justice

Justice is a virtue of the soul that arises from touching wisdom, simplicity and truth. If the souls bowed to each other to submit to the soul. Justice according to Ibn Miskawaih there are 3 parts (ibid):

1) God's justice is what humans do to God, justice for humans must behave in carrying out their obligations towards their creator.

2) Justice among humans is an obligation that must be carried out by humans towards other human beings.

3) Justice towards nature is by preserving nature and using nature as well as possible.

To achieve this, Imam Ibn Miskawaih offered his theory of moral virtue in the position of al wasath (middle). The doctrine of this path has actually been introduced by previous philosophers, such as Mencius, Plato, Aristotle, and the Muslim philosopher Al Kindi. Ibn Miskawaih in general gives the meaning of "middle" (middle way), among others, continuous, moderate, harmony, main, noble, or extreme positions of the advantages and disadvantages of each human soul. For this reason, a law enforcer must also find a middle ground position in combining the functions of sharia and philosophy. Sharia functions effectively for the creation of a middle position in the passionate and courageous souls. Meanwhile, philosophy functions effectively for the creation of a middle position for the soul to think.

Law enforcers must be able to bring love to all humans. Borrowing Ibn Miskawaih's term, humans can achieve all virtues (al fadhilah) is love for all humans. Humans will not reach the level of perfection except by maintaining their kind and showing understanding towards each other. Furthermore, Miskawaih explained that this love will not be visible unless humans are in the middle of society and interact with each other in it. Strictly speaking, the way to achieve excellence here is to develop all psychological aspects and talents through social life, associating with other human beings, so as to obtain other types of happiness that have not been found today. 
According to Ibn Miskawaih, happiness is the peak and perfection of kindness. In this context, happiness that is truly perfect is enjoyed only by special and perfect people. This highest happiness is manifested by trying to let go of the demands of this world and then accepting abundant emanations from above which will perfect the intellect and allow it to be illuminated by Divine light.

Based on the explanation above, the relevance of law must have a transcendental dimension of justice. Where the law is based on ethics (morals) so that it can produce substantive justice instead of mere formalistic justice, where there is a summary of human attitudes to be fair to Allah as the creator, fair to fellow humans, and fair to the universe.

\section{CONCLUSION}

Law enforcement in Indonesia often fails to enforce fair laws. This is because law enforcement in Indonesia is still influenced by positive legal concept that emphasize legal certainty. Where the law is based only on sovereign authority without seeing other principles such as morality, religion, social habits.

In fact, law is to achieve justice, where law enforcers have a duty and responsibility to create justice for society. The law is based on the orders of the authorities and the truth that is embraced by sensory truths. In fact, sensory truth is only relative. According to the progressive legal thinking promoted by Satjipto Raharjo, the law must side with the people. Therefore, in law enforcement in Indonesia, which initially used the paradigm of legal certainty, it must be shifted to a transcendental-based paradigm of justice.

In achieving transcendental-based justice, the author examines the thinking approach of Imam Assyatibi and Imam Ibn Miskawaih which seems to complement how to make perfect humans as enforcers of justice and ethics that can make someone can do justice. The transcendence offered by both Imam Asyathibi and Ibn Miskawaih even completely guides humans to reach Insan Kamil who in their axsiology can bring about justice. The balance of souls between the characteristics of wild beasts, bahimiyah and nathiqoh in the guidance of revelation will certainly produce spiritual intelligence and the ability of a mujtahid (legal expert) not based on mere lust of anger. This is where the transcendental justice dimension of law is relevant. Where law is based on ethics (morals) so that it is able to produce substantive justice instead of mere formalistic justice, where there is a summary 
of human attitudes to be fair to God as the creator, fair to fellow humans and fair to the universe.

\section{REFERENCES}

Ahmadi Absori. The Transcendental Paradigm Of The Develop Of The Law. Journal of Transcendental Law Vol I tahun 2019.

Abu Ishaq Ibrahim bin Musa Asy Syatibi, al-muwafaqot, Dar Ibnu Affan, tt Al-Ghazali, Almushtasyfa minal Ilmi wa al Ushul.

Absori, Transpalasi Nilai Moral dalam Budaya Hukum Berkeadilan (perspektif Hukum Sistemik ke non Sistemik Charles Samford, Prosiding PPPMA 2017

Ahmad, Al-hasyimi Sayyid. Syarah Mukhtaarul Ahaadhts, (Bandung: CV Sinar Baru 1993).

Arief, Sidharta Bernard. Refleksi tentang Struktur Ilmu Hukum Sebuah Penelitian tentang Fundasi Kefilsafatan dan Sifat Keilmuan Ilmu Hukum sebagai Landasan Pengembangan Ilmu Hukum Nasional Indonesia. (Bandung: Mandar Maju, 1999)

Endang Sutrisno, Pemaknaan Budaya Hukum: Menggagas Kesejahteraan Masyarakat, (Bogor: In Media, 2019).

Erwin, Rudy T. Tanya Jawab Filsafat Hukum, (Jakarta: Rineka Cipta, 1969).

Friedman, Lawrence M. The Legal System A Social Science Perspective, (New York: Russell Sage Foundation, 1975).

Friedmann, Teori dan Filsafat Hukum: Telaah Kritis Atas Teori-Teori Hukum (Susunan I), (Jakarta: Rajawali Press, 1996).

Ghofur, Anshori Abdul. Filsafat Hukum Sejarah, Aliran dan Pemaknaan. (Yogyakarta: Gajah Mada University Press, 2006).

Hanitijo, Soemitro Ronny. Perspektif Sosial dalam Pemahaman Masalah-Masalah Hukum, (Semarang: CV Agung, 1989).

Isra, Saldi. Filsafat Hukum (Refleksi Kritis Terhadap Hukum dan Hukum Indonesia (dalam Dimensi Ide dan Aplikasi)), (Depok: PT. Raja Grafindo, 2018).

Izomiddin. Pemikiran dan Filsafat Hukum Islam. (Jakarta: Prenada Media Group, 2018)

Karta Sopetra, Rien G. Pengantar Ilmu Hukum Lengkap, (Bina Aksara, 1983).

Kelsen, Hans. General Theory of Law and State, diterjemahkan oleh Soemardi, Cetakan Pertama, (Jakarta: Rimdi Press, 1995).

Miskawaih, ibnu. Tahdzibulakhlak, Mesir; Kurdistan Al ilmiah 1329.

Menuju Kesempurnaan Akhlak: Buku Daras Pertama tentang Filsafat Etika, diterjemahkan oleh Helmi Hidayat dari Tahdzib al-Akhlak, (Bandung: Mizan, 1999).

Nata, Abuddin. Metodologi Studi Islam. (Jakarta: PT. Raja Grafindo Persada, 2004)

Rahardjo, Satjipto. Aneka Persoalan Hukum dan Masyarakat, (Bandung: Penerbit Alumni, 1983) Publishing, 2009).

. Hukum Progresif Subuah Sintesa Hukum Indonesia, (Yogyakarta: Genta

S.T. Kansil, Pengantar Ilmu Hukum dan Tata Hukum Indonesia, (Jakarta: Balai Pustaka, 1989). 
Syamsul Bakri "Pemikiran Islam dan Filsafat", Jurnal Al-A'raf IAIN Surakarta Vol. XV, NO.1, 2018.

Shidarta. Karakter Penalaran Hukum Dalam Konteks Keindonesiaan, (Bandung: Cv. Utomo, 2006)

Syukri, al-Bani Nasution Muhammad. Filsafat Hukum Islam (Jakarta: PT Raja Grafindo Persada, 2014)

Media Group, 2016)

.Hukum dalam Pendekatan Filsafat. (Jakarta: Prenada 